\title{
GROWTH PERFORMANCE OF GRAIN AMARANTH (AMARANTHUS CRUENTUS L.) ON SPENT ENGINE OIL CONTAMINATED SOIL BIOREMEDIATED WITH TWO BACTERIAL CO-CULTURES AND ORGANIC AMENDMENTS
}

\author{
Adeniyi Olarewaju Adeleye ${ }^{1,2}$, Mohammed Bello Yerima², \\ Michael Edet Nkereuwem³ , Ismail Shina Sadiq ${ }^{4}$, Gimba Peter Shiaka², \\ Victor Odiamehi Onokebhagbe ${ }^{3}$, Afeez Oladeji Amoo ${ }^{1}$

\footnotetext{
${ }^{1}$ Department of Environmental Sciences, Faculty of Science, Federal University Dutse, Ibrahim Aliyu Bye-Pass, P.M.B 7156 - Dutse, Jigawa State, Nigeria

${ }^{2}$ Department of Microbiology and Biotechnology, Faculty of Science, Federal University Dutse, Ibrahim Aliyu Bye-Pass, P.M.B 7156 - Dutse, Jigawa State, Nigeria

${ }^{3}$ Department of Soil Science, Faculty of Agriculture, Federal University Dutse, Ibrahim Aliyu Bye-Pass, P.M.B 7156 - Dutse, Jigawa State, Nigeria

${ }^{4}$ Department of Chemistry, Faculty of Science, Federal University Dutse, Ibrahim Aliyu Bye-Pass, P.M.B 7156 - Dutse, Jigawa State, Nigeria
}

Link to this article: https://doi.org/10.11118/actaun.2021.043

Received: 14. 1.2021, Accepted: 17. 6. 2021

To cite this article: ADELEYE ADENIYI OLAREWAJU, YERIMA MOHAMMED BELLO, NKEREUWEM MICHAEL EDET, SADIQ ISMAIL SHINA, SHIAKA GIMBA PETER, ONOKEBHAGBE VICTOR ODIAMEHI, AMOO AFEEZ OLADEJI. 2021. Growth Performance of Grain Amaranth (Amaranthus Cruentus L.) on Spent Engine Oil Contaminated Soil Bioremediated With Two Bacterial Co-Cultures and Organic Amendments. Acta Universitatis Agriculturae et Silviculturae Mendelianae Brunensis, 69(4): 481-490.

\begin{abstract}
The advent of bioremediation technology has helped scientists to proffer sustainable solutions to problems associated with environmental pollution. Thisstudywasstaged to assess the growth of Amaranthuscruentus L. on spent engine oil (SEO) contaminated soil that had been subjected to bioremediation. Two bacterial cocultures; Pseudomonas aeruginosa+Alcaligenes faecalis and Streptococcus pyogenes + Enterococcus faecalis were bio-enhanced with organic amendments; powdered cow dung (PCD), powdered cocoa pod husk (PCPH) and compost made from cow dung (CD) and cocoa pod husk (CPH) with a view to reclaiming SEO soil at three levels of contamination. It was a factorial experiment laid out with completely randomized design (CRD). Subsequently, amaranth seeds were sown on the experimental pots in the screen house. Results indicated that at two weeks after sowing (2WAS), compost produced significant $(\mathrm{P}<0.05)$ and the highest plant heights $(6.5,7.5$ and $6.1 \mathrm{~cm})$ on all the SEO contamination levels studied compared with other organic amendments. Compost produced the highest (6.0) number of leaves compared with other organic amendments on 10\% SEO contamination level while all the other organic amendments produced the same number of leaves (4.0) on 15\% SEO contamination level. In respect of the stem girths measured in this study, significant performance was recorded at 2WAS, four weeks after sowing (4WAS) and six weeks after sowing (6WAS) $(\mathrm{P}<0.05)$. The significant feat that the bioremediation agents utilized in this study recorded has further confirmed these agents as good candidates that can be adopted in ensuring the reclamation and restoration of SEO ravaged agricultural land.
\end{abstract}

Keywords: bioremediation, bacterial co-cultures, organic amendments, spent engine oil contaminated soil and amaranth 


\section{INTRODUCTION}

Amaranth is extensively cultivated in many regions of the world (Smitha, 2010). The author further reported that Amaranth is cultivated in Nigeria as a source of food and vegetable. According to Tongos (2016), amaranth belongs to the family Amaranthaceace and genus Amaranthus. It has a growing period between 5 and 6 weeks thereby making it advantageous for Nigerian local and periurban farmers to be able to cultivate it as many times they desire on the same agricultural soil in a year (Adewole and Igberaese, 2011; Adewole and Dedeke, 2012). In recent times, renewed research interest in amaranth is connected with its outstanding attributes ranging from adaptation to extreme growing conditions, resistance of drought and heat, resistance of major diseases, huge genetic diversity, ease of planting and phenotypic plasticity (Rastogi and Shukla, 2013).

Over the years, scientists have been exploiting the encouraging prospects of bioremediation technology in solving petroleum hydrocarbon related pollution that has been ravaging our environment these days. According to Bundy et al. (2002), spillage of crude oil and other petroleum hydrocarbons on soil is a global environmental problem that regularly requires being cleaned up. The damaging effect of the presence of any form of petroleum hydrocarbons on soil is its ability to make water, oxygen and nitrogen unavailable for plant growth thereby rendering such agricultural soil unproductive (Adam and Duncan, 2002). Soil contamination related to petroleum hydrocarbon adversely affected the growth parameters of the plant height, plant biomass and leaf area of Paspalum scrobiculatum (Ogbo et al., 2009) and reduction in plant height of experimental plant (Molina-Baharahona et al., 2005). It has been reported by Yerima et al. (2013); Umana et al. (2017), that the presence of spent engine oil (SEO) on agricultural soil exposes it to varying levels of toxicity inherently linked with polyaromatic hydrocarbons (PAHs). Hydrocarbons typically initiate the expulsion of oxygen in the soil through suffocation of soil particles thereby hindering the diffusion of air in the pores which invariably affects biodiversity of soil microbial consortium (Wang et al., 2013). According to Osaigbovo et al. (2013), SEO has got the capability to deplete nitrogen and phosphorous from agricultural soil coupled with inhibiting various activities of microorganisms present therein.

One of the first steps required for the selection of plant species for any bioremediation project is their capability to grow in contaminated soil coupled with their degradative potential on petroleum hydrocarbons when present in agricultural soils (Merkl et al., 2004). Owing to numerous findings that have been reported in the literature as regards the proficiency of bioremediation technology in cleaning up petroleum hydrocarbon related environmental pollution, this study aimed to assess the growth performance of Amaranthus cruentus on SEO contaminated soil that had undergone bioremediation with the aid of processed organic amendments and some selected bacterial inoculants. The study was staged based on the null hypothesis that stated that the application of organic amendments does not enhance reclamation of SEO contaminated soil.

\section{MATERIALS AND METHODS}

This study was conducted at the back of the Department of Soil Science, Faculty of Agriculture located on Federal University Dutse campus (Lat $11^{\circ} 46$ '39”N and Long 9²0'3”'E) Jigawa state, Nigeria. This experimental design was factorial adopting completely randomized design (CRD) with three replicates each. There were two factors; Organic amendments with four (4) levels (control, compost, processed cocoa pod husk and processed cow dung) and SEO at three (3) levels (5, 10 and 15\%) giving a total of twelve treatment combinations. The factors are listed below.

\section{Factors}

a) Organic amendments (150 g)

- No organic amendment (control)

- Compost

- Processed cocoa pod husk

- Processed cow dung

\section{b) SEO}

- $5 \%(75 \mathrm{~mL})$

- $10 \%(150 \mathrm{~mL})$

- 15\% (225 mL)

The soil and organic amendments were analysed using standardized procedures. The mechanical analysis and moisture content of the soil were carried out by the procedure outlined by Pansu and Gautheyrou (2003) while electrical conductivity and $\mathrm{pH}$ in water were determined using the procedure outlined by Dwivedi and Baghel (2015). Organic carbon was determined by the wet oxidation method of Walkley and Black as described by Nelson and Sommers (1986). Total nitrogen was determined using the micro-Kjeldahl digestion method. Content of nitrogen in the digest was determined by colorimeter as described by Bremmer (1996). Available phosphorous was extracted using Mehlich-3 extractant and phosphorous was quantified using the Jenway 6320D spectrophotometer. Exchangeable bases and cation exchange capacity (CEC) were determined using ammonium acetate solution to saturate the samples. Calcium and magnesium in the filtrate were determined using Atomic Absorption Spectrophotometer (Buck 211VGP) while potassium and sodium were quantified using a flame photometer (Jenway PFP7). Cation exchange capacity in the filtrate was determined by titrating excess ammonium acetate with ethanol. 
About $10 \mathrm{~g}$ of soil that had undergone pollution with SEO was collected at a depth of $5 \mathrm{~cm}$ from the mechanic village in Dutse, Northwest Nigeria. The bacteria; Pseudomonas aeruginosa, Alcaligenes faecalis, Streptococcus pyogenes and Enterococcus faecalis employed as inoculants for bioaugmentation were isolated and identified in reference to Adeleye and Yerima (2019). These bacteria were subsequently paired as co-cultures and employed for the biodegradation assay.

After staging the biodegradation assay for seventy days as earlier reported by Adeleye et al. (2020), and the experimental pots were transferred into the screen house, seeds of Amaranthus curentus were sown with a view to assessing the bacterial reclamation of the SEO contaminated soil for six weeks.

Having sown the Amaranthus curentus seeds, stem girth, plant height and number of leaves were determined at two weeks after sowing (2WAS), four weeks after sowing (4WAS) and six weeks after sowing (6WAS). The stem girth was measured with a rope and subsequently placed on a meter rule in centimeter while the plant height was measured with a meter rule in centimeter. The number of leaves was estimated through the aid of visual counting. All data collected from the screen house were subjected to analysis of variance (ANOVA) by Proc. GLM of GenStat version 17, and significant means were subsequently separated using Duncan Multiple Range Test (DMRT).

\section{RESULTS}

The physical and chemical properties of the soil and organic amendments are presented in Tab. I. The sum of exchangeable bases of the soil used in this study recorded $3.51 \mathrm{cmol}^{-\mathrm{kg}^{-1}}$ while that of powdered cow dung (PCD), powdered cocoa pod husk (PCPH) and compost recorded $82.1 \mathrm{cmol} \mathrm{kg}^{-1}$, $166.15 \mathrm{cmolkg}^{-1}$ and $221.7 \mathrm{cmol} \mathrm{kg}^{-1}$ respectively. $\mathrm{pH}$ (in water) of the soil indicated slight acidity while that of organic amendments indicated slight alkalinity to alkalinity (Tab. I).

\section{Effect of Organic Amendments on the Growth Performance of Amaranthus cruentus in SEO Bioremediated Soil Using Pseudomonas aeruginosa and Alcaligenes faecalis co-culture}

Amaranthus cruentus growing under SEO bioremediated soil is depicted in Fig 1. Results generated on all the growth parameters indicate that at 2WAS, compost produced significant $(\mathrm{P}<0.05)$ and the highest plant heights $(6.5,7.5$ and $6.1 \mathrm{~cm})$ on all the SEO contamination levels studied compared with other organic amendments (Tab. II). At 4WAS, compared with other organic amendments, compost repeated the same feat by producing the highest plant heights $(17.3,18.0$ and $17.5 \mathrm{~cm})$ on $5 \%$, $10 \%$ and $15 \%$ SEO contamination levels respectively

I: Physicochemical properties of the soil and organic amendments used for the experiment

\begin{tabular}{|c|c|c|c|c|}
\hline Moisture content (\%) & 2.04 & 7.3 & 11.11 & 2.0 \\
\hline $\mathrm{pH}_{\text {(water) }}$ & 6.5 & 8.15 & 7.6 & 9.45 \\
\hline Organic Carbon (\%) & 0.49 & 41.55 & 33.40 & 48.25 \\
\hline Available Phosphorous (mg kg-1) & 11.02 & 1.2 & 0.08 & 1.48 \\
\hline $\mathrm{EC}\left(\mathrm{dS} \mathrm{cm} \mathrm{cm}^{-1}\right)$ & 0.92 & 8.10 & 6.42 & 8.86 \\
\hline \multicolumn{5}{|c|}{ Exchangeable Bases (cmol.kg-1) } \\
\hline Magnesium & 0.92 & 1.5 & 2.45 & 3.24 \\
\hline Sodium & 0.58 & 0.4 & 0.1 & 0.5 \\
\hline CEC & 3.51 & 82.1 & 166.15 & 221.7 \\
\hline \multicolumn{5}{|c|}{ Particle Size (g.kg-1) } \\
\hline Clay + Silt & 420 & - & - & - \\
\hline Clay & 100 & - & - & - \\
\hline Silt & 320 & - & - & - \\
\hline
\end{tabular}

- : No value; PCD: Powdered cow dung; PCPH: Powdered cocoa pod husk 
(Tab. III). However, at 6WAS, all the plant heights enhanced by all the organic amendments were not significantly $(\mathrm{P}>0.05)$ different from each other. At 6WAS, compost produced the highest plant heights $(30.5,30.8$ and $29.7 \mathrm{~cm})$ on $5 \%, 10 \%$ and $15 \%$ SEO contamination levels respectively compared to other organic amendments although it was not significantly different (Tab. IV).

Results obtained from the number of leaves indicate that all the organic amendments did

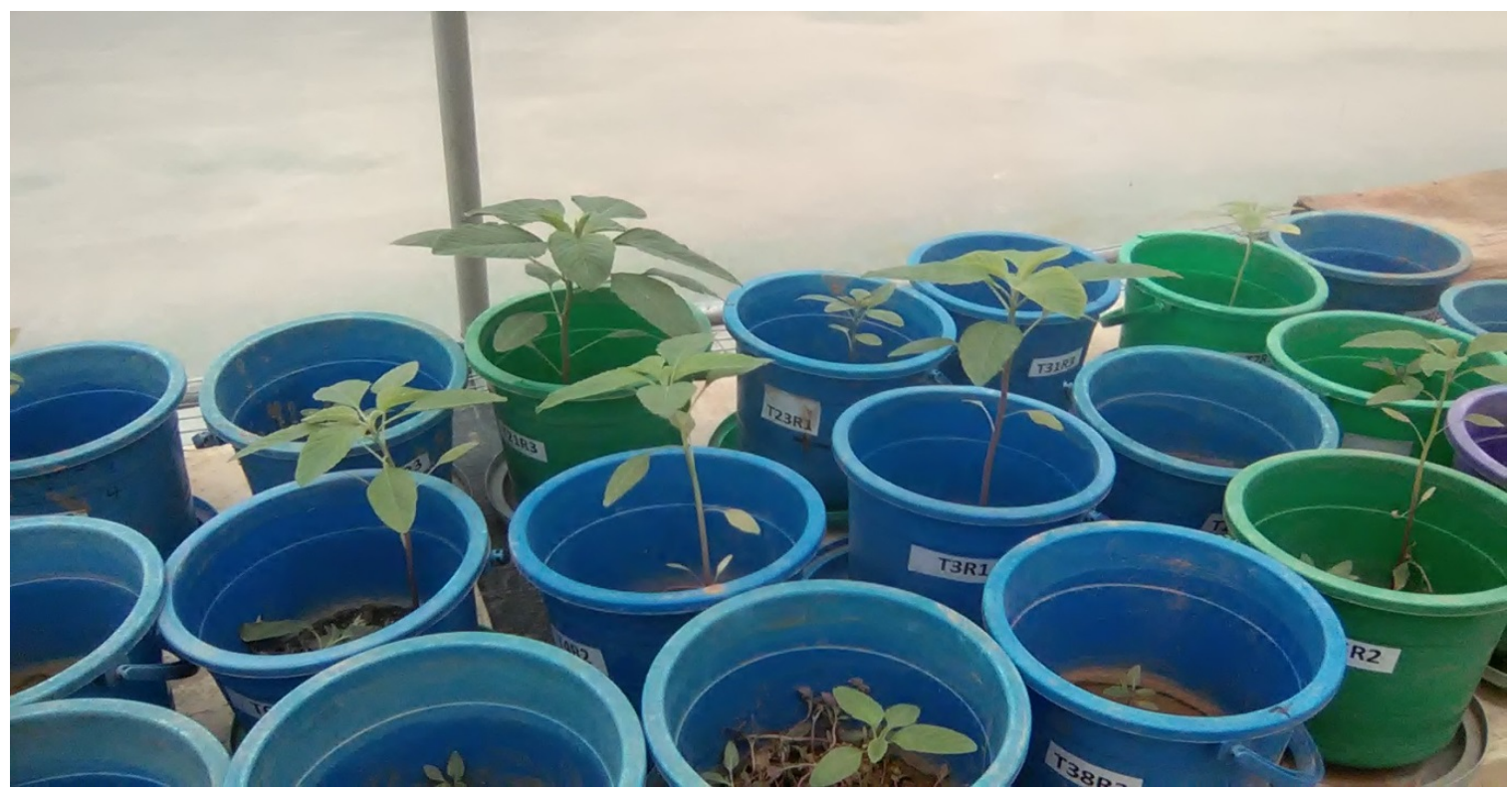

1: Amaranthus curentus growing under bioremediated spent engine contaminated soil in the screen house

II: Growth performance of test plant on SEO contaminated soil bioremediated with organic amendments together with Pseudomonas aeruginosa and Alcaligenes faecalis co-culture at 2 WAS

\begin{tabular}{|c|c|c|c|c|c|c|c|c|c|}
\hline \multirow{3}{*}{$\begin{array}{c}\text { Organic } \\
\text { amendments }\end{array}$} & \multicolumn{9}{|c|}{ SEO contamination levels } \\
\hline & $5 \%$ & $10 \%$ & $15 \%$ & $5 \%$ & $10 \%$ & $15 \%$ & $5 \%$ & $10 \%$ & $15 \%$ \\
\hline & \multicolumn{3}{|c|}{ Plant height $(\mathrm{cm})$} & \multicolumn{3}{|c|}{ Number of leaves } & \multicolumn{3}{|c|}{ Stem girth $(\mathrm{cm})$} \\
\hline Compost & $6.5^{b}$ & $7.5^{\mathrm{a}}$ & $6.1^{\mathrm{e}}$ & 4.0 & 6.0 & 4.0 & $1.1^{\mathrm{b}}$ & $1.4^{\mathrm{a}}$ & $0.9^{c}$ \\
\hline CPH only & $6.4^{\mathrm{c}}$ & $5.8^{\mathrm{f}}$ & $5.5^{\mathrm{g}}$ & 5.0 & 4.0 & 4.0 & $0.9^{c}$ & $0.6^{e}$ & $0.5^{\mathrm{f}}$ \\
\hline CD only & $6.2^{\mathrm{d}}$ & $4.7^{\mathrm{h}}$ & $4.5^{\mathrm{i}}$ & 4.0 & 3.0 & 4.0 & $0.8^{\mathrm{d}}$ & $0.6^{\mathrm{e}}$ & $0.5^{\mathrm{f}}$ \\
\hline Control & $0.0^{j}$ & $0.0^{\mathrm{j}}$ & $0.0^{\mathrm{j}}$ & 0.0 & 0.0 & 0.0 & $0.0^{g}$ & $0.0^{g}$ & $0.0^{g}$ \\
\hline Significance status & & & & Ns & Ns & Ns & & & \\
\hline
\end{tabular}

Means with the same letters in each column are not significantly different using Duncan's multiple range test (DMRT). Ns: Not significant. $(\mathrm{P}<0.05)$

III: Growth performance of test plant on SEO contaminated soil bioremediated with organic amendments together with Pseudomonas aeruginosa and Alcaligenes faecalis co-culture at $4 W A S$

\begin{tabular}{|c|c|c|c|c|c|c|c|c|c|}
\hline \multirow{3}{*}{$\begin{array}{c}\text { Organic } \\
\text { amendments }\end{array}$} & \multicolumn{9}{|c|}{ SEO contamination levels } \\
\hline & $5 \%$ & $10 \%$ & $15 \%$ & $5 \%$ & $10 \%$ & $15 \%$ & $5 \%$ & $10 \%$ & $15 \%$ \\
\hline & \multicolumn{3}{|c|}{ Plant height $(\mathrm{cm})$} & \multicolumn{3}{|c|}{ Number of leaves } & \multicolumn{3}{|c|}{ Stem girth $(\mathrm{cm})$} \\
\hline Compost & $17.3^{\mathrm{c}}$ & $18.0^{\mathrm{a}}$ & $17.5^{\mathrm{b}}$ & 5.0 & 6.0 & 4.0 & $1.8^{\mathrm{b}}$ & $1.6^{\mathrm{d}}$ & $1.7^{c}$ \\
\hline $\mathrm{CPH}$ only & $17.1^{\mathrm{d}}$ & $16.4^{\mathrm{e}}$ & $15.8^{\mathrm{f}}$ & 5.0 & 4.0 & 4.0 & $1.3^{e}$ & $2.6^{\mathrm{a}}$ & $1.2^{\mathrm{f}}$ \\
\hline CD only & $13.5^{\mathrm{g}}$ & $9.3^{\mathrm{h}}$ & $7.6^{\mathrm{i}}$ & 5.0 & 4.0 & 4.0 & $1.3^{e}$ & $1.2^{\mathrm{f}}$ & $0.8^{\mathrm{g}}$ \\
\hline Control & $0.0^{\mathrm{j}}$ & $0.0^{\mathrm{j}}$ & $0.0^{\mathrm{j}}$ & 0.0 & 0.0 & 0.0 & $0.0^{\mathrm{h}}$ & $0.0^{\mathrm{h}}$ & $0.0^{\mathrm{h}}$ \\
\hline Significance status & & & & Ns & Ns & Ns & & & \\
\hline
\end{tabular}

Means with the same letters in each column are not significantly different using Duncan's multiple range test (DMRT). Ns: Not significant. $(\mathrm{P}<0.05)$ 
IV: Growth performance of test plant on SEO contaminated soil bioremediated with organic amendments together with Pseudomonas aeruginosa and Alcaligenes faecalis co-culture at 6WAS

\begin{tabular}{|c|c|c|c|c|c|c|c|c|c|}
\hline \multirow{3}{*}{$\begin{array}{c}\text { Organic } \\
\text { amendments }\end{array}$} & \multicolumn{9}{|c|}{ SEO contamination levels } \\
\hline & $5 \%$ & $10 \%$ & $15 \%$ & $5 \%$ & $10 \%$ & $15 \%$ & $5 \%$ & $10 \%$ & $15 \%$ \\
\hline & \multicolumn{3}{|c|}{ Plant height $(\mathrm{cm})$} & \multicolumn{3}{|c|}{ Number of leaves } & \multicolumn{3}{|c|}{ Stem girth $(\mathrm{cm})$} \\
\hline Compost & 30.5 & 30.8 & 29.7 & 9.0 & 10.0 & 8.0 & $2.9^{b}$ & $3.1^{\mathrm{a}}$ & $2.5^{\mathrm{d}}$ \\
\hline $\mathrm{CPH}$ only & 30.6 & 28.2 & 27.9 & 8.0 & 8.0 & 7.0 & $2.7^{c}$ & $2.7^{c}$ & $2.1^{\mathrm{f}}$ \\
\hline CD only & 28.5 & 28.1 & 20.2 & 7.0 & 8.0 & 7.0 & $2.3^{e}$ & $1.9^{\mathrm{g}}$ & $1.9^{g}$ \\
\hline Control & 0.0 & 0.0 & 0.0 & 0.0 & 0.0 & 0.0 & $0.0^{\mathrm{h}}$ & $0.0^{\mathrm{h}}$ & $0.0^{\mathrm{h}}$ \\
\hline Significance status & Ns & Ns & Ns & Ns & Ns & Ns & & & \\
\hline
\end{tabular}

Means with the same letters in each column are not significantly different using Duncan's multiple range test (DMRT). Ns: Not significant. $(\mathrm{P}<0.05)$

not significantly enhance it $(\mathrm{P}>0.05)$. At 2WAS, powdered $\mathrm{CPH}$ only produced the highest number of leaves (5.0) compared with other organic amendments on 5\% SEO contamination level (Tab. I). Compost produced the highest (6.0) number of leaves compared with other organic amendments on $10 \%$ SEO contamination level while all the organic amendments produced the same number of leaves (4.0) on 15\% SEO contamination level (Tab. II). At 4WAS, all the organic amendments produced the same number of leaves (5.0) on 5\% SEO contamination level, compost recorded the highest number of leaves (6.0) on 10\% SEO contamination level while all the organic amendments produced the same number of leaves (4.0) on 15\% SEO contamination level (Tab. III). At 6WAS, compared with other organic amendments, compost produced the highest number of leaves (9.0, 10.0 and 8.0) on 5\%, 10\% and 15\% SEO contamination levels respectively (Tab. IV).

In respect of the stem girths measured in this study, significant performance was recorded at 2WAS, 4WAS and 6WAS ( $\mathrm{P}<0.05$ ). Compared with other organic amendments employed, compost produced the best stem girths $(1.1,1.4$ and $0.9 \mathrm{~cm})$ on $5 \%, 10 \%$ and $15 \%$ SEO contamination levels respectively (Tab. II). At 4WAS, compared with other organic amendments utilized, compost produced the best stem girths (1.8 and $1.7 \mathrm{~cm}$ ) on 5\% and 15\% SEO contamination levels while powdered $\mathrm{CPH}$ only facilitated the most stem girth $(2.6 \mathrm{~cm})$ on $10 \%$ SEO contamination level (Tab. III). Meanwhile, at 6WAS, compared with other organic amendments, compost produced the best stem girths (2.9, 3.1 and $2.5 \mathrm{~cm}$ ) on $5 \%, 10 \%$ and $15 \%$ SEO contamination levels respectively (Tab. IV).

\section{Effect of Organic Amendments on the Growth Performance of Amaranthus cruentus in SEO Bioremediated Soil Using Streptococcus pyogenes and Enterococcus faecalis co-culture}

Results obtained on the growth pattern of Amaranthus cruentus planted on experimental bags biostimulated with organic amendments and bioaugmented using Streptococcus pyogenes and Enterococcus faecalis co-culture indicate significant effect $(\mathrm{P}<0.05)$ at $2 \mathrm{WAS}$ and 4 WAS but insignificant effect was demonstrated at 6WAS $(\mathrm{P}>0.05)$ on plant heights. Specifically, at 2WAS, compost enhanced the highest plant heights (6.2, 7.1 and $5.9 \mathrm{~cm}$ ) compared with other organic amendments on 5\%, 10\% and 15\% SEO contamination levels respectively (Tab. V). At 4WAS, compared with other organic amendments, compost influenced the highest plant heights (18.1, 18.2 and $17.3 \mathrm{~cm})$ on $5 \%, 10 \%$ and $15 \%$ SEO contamination levels respectively (Tab. VI). However, at 6WAS, compared with other organic amendments, compost produced the highest but insignificant plant heights (29.5, 30.4 and $29.0 \mathrm{~cm}$ ) on 5\%, 10\% and 15\% SEO contamination levels respectively (Tab. VII).

Regarding the number of leaves produced by Amaranthus cruentus at 2WAS, compost produced the most (5.0) compared with other organic amendments on $5 \%$ and $10 \%$ SEO contamination levels while both compost and powdered CD only enhanced the production of the most number of leaves (4.0) on 15\% SEO contamination level (Tab. V). At 4WAS, compared with other organic amendments, compost produced the most number of leaves (5.0 and 6.0) compared with other amendments on $5 \%$ and $10 \%$ SEO contamination levels respectively while both compost and powdered $\mathrm{CD}$ only produced the most number of leaves (4.0) on 15\% SEO contamination level (Tab. VI).

At 6WAS, compared with powdered CD only, both compost and powdered $\mathrm{CPH}$ only produced the most number of leaves (9.0) on 5\% SEO contamination level (Tab. VI). Compost produced the most number of leaves (10.0) compared with other organic amendments on 10\% SEO contamination level while both compost and powdered CPH only produced the most number of leaves (8.0) on $15 \%$ SEO contamination level (Figs. 2 and 3).

All the organic amendments adopted significantly enhanced better performance of the stem girths measured in this study $(\mathrm{P}<0.05)$. At $2 \mathrm{WAS}$, related 
V: Growth performance of test plant on SEO contaminated soil bioremediated with organic amendments together with Streptococcus pyogenes and Enterococcus faecalis co-culture at 2 WAS

\begin{tabular}{|c|c|c|c|c|c|c|c|c|c|}
\hline \multirow{3}{*}{$\begin{array}{c}\text { Organic } \\
\text { amendments }\end{array}$} & \multicolumn{9}{|c|}{ SEO contamination levels } \\
\hline & $5 \%$ & $10 \%$ & $15 \%$ & $5 \%$ & $10 \%$ & $15 \%$ & $5 \%$ & $10 \%$ & $15 \%$ \\
\hline & \multicolumn{3}{|c|}{ Plant height $(\mathrm{cm})$} & \multicolumn{3}{|c|}{ Number of leaves } & \multicolumn{3}{|c|}{ Stem girth $(\mathrm{cm})$} \\
\hline Compost & $6.2^{c}$ & $7.1^{\mathrm{a}}$ & $5.9^{d}$ & 5.0 & 5.0 & 4.0 & $1.0^{\mathrm{b}}$ & $1.2^{\mathrm{a}}$ & $0.8^{\mathrm{d}}$ \\
\hline $\mathrm{CPH}$ only & $5.5^{e}$ & $4.2^{\mathrm{h}}$ & $4.3^{\mathrm{g}}$ & 4.0 & 3.0 & 3.0 & $0.9^{c}$ & $0.6^{\mathrm{e}}$ & $0.5^{\mathrm{f}}$ \\
\hline CD only & $5.9^{d}$ & $6.3^{b}$ & $4.8^{\mathrm{f}}$ & 4.0 & 4.0 & 4.0 & $0.8^{\mathrm{d}}$ & $0.6^{e}$ & $0.5^{f}$ \\
\hline Control & $0.0^{\mathrm{i}}$ & $0.0^{\mathrm{i}}$ & $0.0^{\mathrm{i}}$ & 0.0 & 0.0 & 0.0 & $0.0^{g}$ & $0.0^{\mathrm{g}}$ & $0.0^{\mathrm{g}}$ \\
\hline \multicolumn{4}{|l|}{ Significance status } & Ns & Ns & Ns & & & \\
\hline \multicolumn{10}{|c|}{$\begin{array}{l}\text { Means with the same letters in each column are not significantly different using Duncan's multiple range test (DMRT) } \\
\text { Ns: Not significant. }(\mathrm{P}<0.05)\end{array}$} \\
\hline \multicolumn{10}{|c|}{$\begin{array}{l}\text { VI: Growth performance of test plant on SEO contaminated soil bioremediated with organic amendments together wit } \\
\text { Streptococcus pyogenes and Enterococcus faecalis co-culture at } 4 \text { WAS }\end{array}$} \\
\hline \multirow{3}{*}{$\begin{array}{c}\text { Organic } \\
\text { amendments }\end{array}$} & \multicolumn{9}{|c|}{ SEO contamination levels } \\
\hline & $5 \%$ & $10 \%$ & $15 \%$ & $5 \%$ & $10 \%$ & $15 \%$ & $5 \%$ & $10 \%$ & $15 \%$ \\
\hline & \multicolumn{3}{|c|}{ Plant height $(\mathrm{cm})$} & \multicolumn{3}{|c|}{ Number of leaves } & \multicolumn{3}{|c|}{ Stem girth $(\mathrm{cm})$} \\
\hline Compost & $18.1^{\mathrm{b}}$ & $18.2^{\mathrm{a}}$ & $17.3^{\mathrm{d}}$ & 5.0 & 6.0 & 4.0 & $1.4^{\mathrm{d}}$ & $1.6^{\mathrm{b}}$ & $1.5^{c}$ \\
\hline CPH only & $15.7^{\mathrm{e}}$ & $6.3^{\mathrm{h}}$ & $6.20^{\mathrm{i}}$ & 4.0 & 4.0 & 3.0 & $1.3^{\mathrm{e}}$ & $2.4^{\mathrm{a}}$ & $1.2^{\mathrm{f}}$ \\
\hline CD only & $12.6^{\mathrm{f}}$ & $18.0^{c}$ & $11.2^{\mathrm{g}}$ & 4.0 & 5.0 & 4.0 & $1.3^{\mathrm{e}}$ & $1.2^{\mathrm{f}}$ & $0.9^{g}$ \\
\hline Control & $0.0^{j}$ & $0.0^{j}$ & $0.0^{\mathrm{j}}$ & 0.0 & 0.0 & 0.0 & $0.0^{\mathrm{h}}$ & $0.0^{\mathrm{h}}$ & $0.0^{\mathrm{h}}$ \\
\hline Significance status & & & & Ns & Ns & Ns & & & \\
\hline
\end{tabular}

Means with the same letters in each column are not significantly different using Duncan's multiple range test (DMRT). Ns: Not significant. $(\mathrm{P}<0.05)$

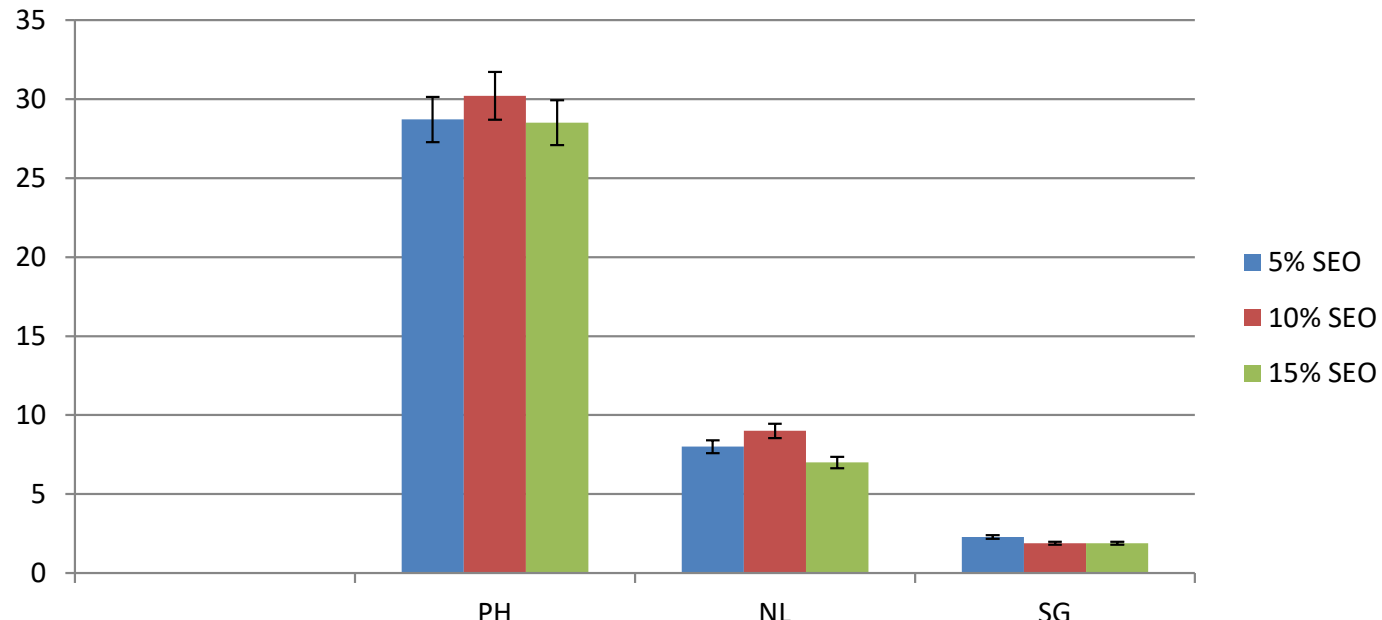

2: Growth performance of Amarantus cruentus bioremediated with compost and Streptococcus pyogenes + Enterococcus faecalis co-culture at 6WAS.

PH denotes plant height, NL denotes number of leaves, SG denotes stem girth.

with other amendments employed, compost produced the best results $(1.0,1.2$ and $0.8 \mathrm{~cm})$ on $5 \%$, $10 \%$ and $15 \%$ SEO contamination levels respectively (Tab. V). At 4WAS, compost produced the best results (1.4 and $1.5 \mathrm{~cm}$ ) on 5\% and 10\% SEO contamination level respectively while powdered $\mathrm{CPH}$ only facilitated the best result $(2.4 \mathrm{~cm})$ on $15 \%$ SEO contamination level compared with other organic amendments adopted (Tab. VI). However, at 6WAS, compost continued its significant feat by producing the best stem girths (2.8 and $2.3 \mathrm{~cm}$ ) on $10 \%$ and 15\% SEO contamination levels respectively while powdered $\mathrm{CPH}$ only facilitated the best stem girth $(2.7 \mathrm{~cm}$ ) on $5 \%$ SEO contamination level (Fig. 2). 


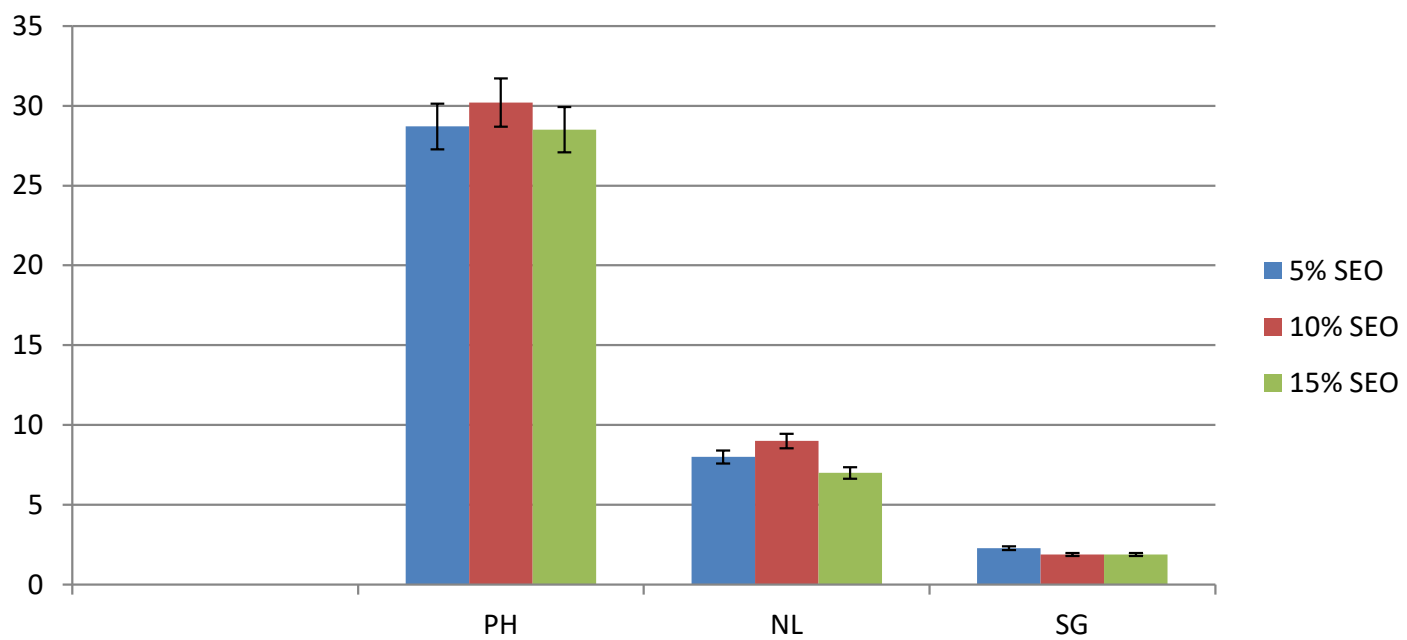

3: Growth performance of Amarantus cruentus bioremediated with compost and Streptococcus pyogenes + Enterococcus faecalis co-culture at 6WAS.

$\mathrm{PH}$ denotes plant height, NL denotes number of leaves, SG denotes stem girth.

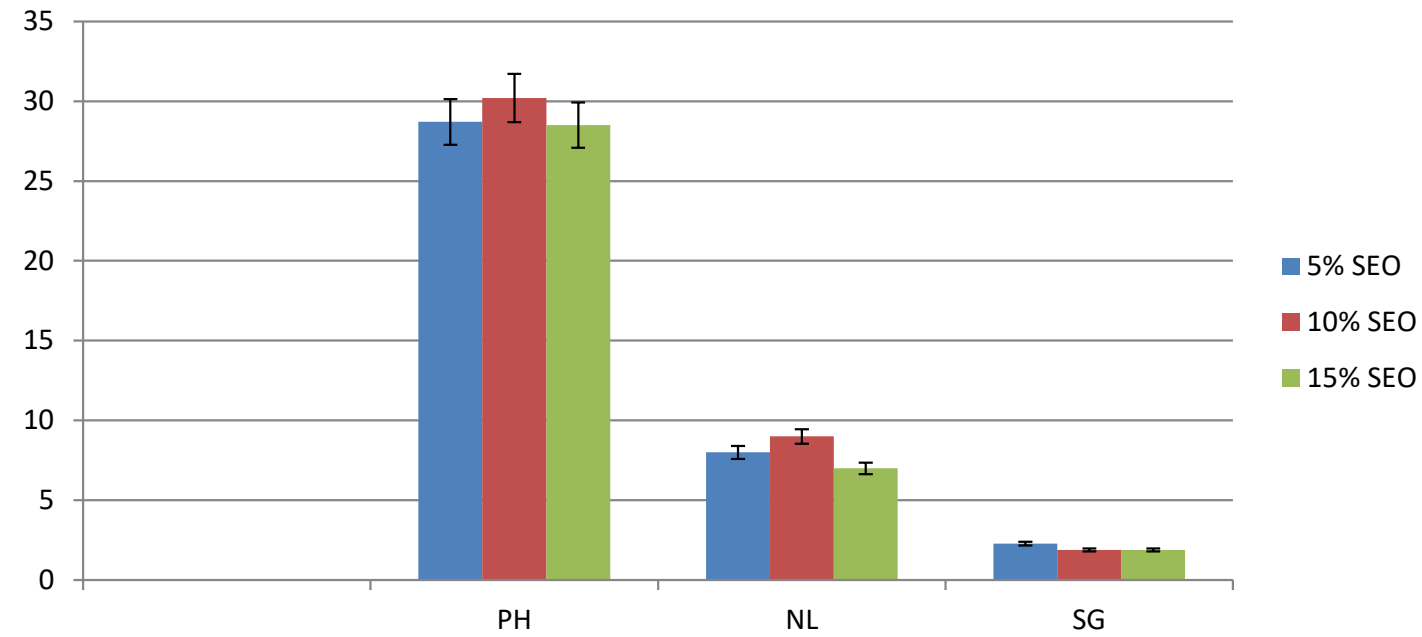

4: Growth performance of Amarantus cruentus bioremediated with compost and Streptococcus pyogenes + Enterococcus faecalis co-culture at 6WAS.

PH denotes plant height, NL denotes number of leaves, SG denotes stem girth.

Nevertheless, PCD produced the least $(1.9 \mathrm{~cm})$ stem girth on $10 \%$ and $15 \%$ SEO contamination levels respectively (Fig. 4).

\section{DISCUSSION}

The prospect of bioremediation technology in effecting desirable reclamation of polluted environment has been reported by Okoye et al. (2017); Sivaramakrishnan et al. (2021) coupled with the employment of amaranths for bioremediation studies which Chinmayee et al. (2012); Rehaman et al. (2020) have submitted to have produced promising results over the years. The ability of suitable organic amendments to facilitate operational reclamation of SEO polluted soil has equally been reported by Osaigbovo et al. (2013).

Results generated from the experimental pots used as control clearly indicated that SEO has the capability of not supporting the growth of plants on agricultural soils as Amaranthus cruentus seeds sown did not grow on it at all. Despite the acclaimed ability of growing under unfavourable conditions that Rastogi and Shukla (2013) reported about amaranths, the incapability of the seeds to grow on the experimental pots adopted as control is an evidence of the presence of reasonable concentration of SEO that did not undergo bioremediation in this study. This finding supports the reports of Agbogidi et al. (2007); Onwurah et al. (2007) on the aptitude of petroleum hydrocarbons to cause soil sterility thus inhibiting germination of seeds, growth and yield of agricultural crops. Again, petroleum hydrocarbons establish negative conditions that make nitrogen and oxygen that are needed for plant growth unavailable for such purpose (Adam and Duncan, 2002). 
As witnessed in this study, several authors (Smith et al., 2006; Olson et al., 2007; Abii and Nwosu, 2009; Inckot et al., 2011) have submitted that germination of seeds and growth parameters of plants can be negatively affected by the deleterious effects of hydrocarbons. The significant growth parameters of Amaranthus cruentus recorded in this study could be credited to the supplementation of the SEO contaminated soil with organic nutrients that aided its bacterial reclamation thereby leading to its supporting agricultural production significantly. Similar submissions have been made by Kyung-Hwa et al. (2004); Adedokun and Ataga (2007); Njoku et al. (2008); Nwadinigwe and Onyeidu (2012) on the ability of biostimulation and bioaugmentation to restore hydrocarbon polluted soil thereby attaining significant improvement in the growth of the test crops employed in their respective studies.

The feat attained by the organic amendments utilized in this study in terms of enhancing significant growth pattern of Amaranthus cruentus most especially plant heights and stem girths can be associated with the supply of essential nutrients and favourable conditions required for its growth as those sown on the experimental bags employed as control did not germinate at all. Similar report has been submitted by Adenipekun et al. (2008) who observed that their test plant did not grow on the SEO polluted soil studied. Similar catastrophic effect of hydrocarbons in having the tendency to block the pore space of terrestrial vegetation which invariably leads to poor performance of plants has been equally reported by Ekpo and Nwankpa (2005); Ogbo et al. (2009). The non-significance trend documented across experimental pots in terms of number of leaves produced on the bioremediated SEO contaminated soil in this study could be attributed to lower total nitrogen content earlier reported by Osaigbovo et al. (2013). The results obtained in this study corroborate the submission of Agbor et al. (2015), that bioremediation remains a better tool that can be employed in attaining optimum growth of plants meant to be planted on hydrocarbon polluted soil.

\section{CONCLUSION}

Based on the results obtained in this study, the null hypothesis initially stated is hereby rejected as the bioenhancement of spent engine oil contaminated soil with the bacterial co-cultures and organic amendments resulted in significant removal of hydrocarbon components that should have impaired the growth of Amaranthus cruentus sown on the artificially contaminated soil. However, spent engine oil contaminated soil that was bioremediated with the combination of compost and Pseudomonas aeruginosa+Alcaligenes faecalis co-culture produced the highest plant height and most stem girth while those bioremediated with the two bacterial co-cultures and compost produced the most and same number of leaves at six weeks after sowing. The significant performance of the bioremediation agents on the agronomic variables measured in this study has made these agents potential candidates that can be adopted in ensuring the reclamation and restoration of spent engine oil ravaged agricultural land. The bioremediation agents employed in this study are thus recommended as cost-effective and environment friendly options that can be utilized by local and poor farmers that may require the technology in combating petroleum hydrocarbon and other related environmental pollution problems on their agricultural land.

\section{REFERENCES}

ABII, T. A. and NWOSU, P. C. 2009. The Effect of Oil-Spillage on the Soil of Eleme in Rivers State of the Niger Delta Area of Nigeria. Research Journal of Environmental Sciences, 3(3): 316-320.

ADAM, G. and DUNCAN, H. J. 2002. Influence of Diesel Fuel on Seed Germination. Environmental Pollution, 120(2): 363-370.

ADEDOKUN, O. M. and ATAGA, A. E. 2007. Effects of Amendments and Bioaugumentation of Soil Polluted with Crude oil, Automotive Gasoline Oil, and Spent Engine Oil on the Growth of Cowpea (Vigna ungiculata L. walp). Scientific Research and Essay, 2(5): 147-149.

ADELEYE, A. O. and YERIMA, M. B. 2019. Isolation and identification of spent engine oil utilizing bacteria from Mechanic Village Dutse, Jigawa State. Paper presented at the $42^{\text {nd }}$ Conference of the Nigerian Society for Microbiology. Igbesa, Ogun State, Nigeria: Crawford University.

ADELEYE, A. O., YERIMA, M. B., NKEREUWEM, M. E., ONOKEBHAGBE, V. O., SHIAKA, P. G., AMOO, F. K., ADAM, I. K., SADIQ, I. S., OLALEYE, A. A., RAJI, M. and ALIYU, A. 2020. Enhanced Degradation of Hydrocarbons in Spent Engine Oil Contaminated Soil by Pseudomonas aeruginosa and Alcaligenes faecalis. FUW Trends in Science \& Technology Journal, 5(2): 437-444.

ADENIPEKUN, C. O., OYETUNJI, O. J. and KASSIM, L. S. 2008. Effect of Spent Engine Oil on the Growth Parameters and Chlorophyll Content of Corchorus olitorius Linn. Environmentalist, 28: 446-450. 
ADEWOLE, M. B. and DEDEKE, O. A. 2012. Growth Performance, Yield and Nutritional Quality of Amaranthus Cruentus L. under repeated Applications of Poultry Manures. Ife Journal of Science, 14(2): 345-355.

ADEWOLE, M. B. and IGBERAESE, S. O. 2011. Growth, yield and sensory properties of organically produced Amaranthus hybridus Linn. In: SALAMI, A. T. and ORIMOOGUNJE, O. O. I. (Eds.). Environmental research and challenges of sustainable development in Nigeria. Ile-Ife, Nigeria: Obafemi Awolowo University Press, pp. 454-465.

AGBOGIDI, O. M., ERUOTOR, P. G. and AKPAROBI, S. O. 2007. Effects of Time of Application of Crude Oil to Soil on the Growth of Maize (Zea mays L.). Research Journal of Environmental Toxicology, 1(3): 116-123.

AGBOR, R. B., EKPO, I. A., KALU, S. E., BASSEY, I. U., OKOI, E. P. and UDE, E. O. 2015. Growth Pattern of Two Crop Species on Bio-Remediated Hydrocarbon Polluted Soils. Academic journals, 10(2): 58-63.

BREMMER, J. M. 1996. Nitrogen-Total. In: MILLER, A. and KEENY, D. Methods of soil analysis. Madison, USA: American Society of Agronomy, pp. 595-624.

BUNDY, J. G., PATON, G. I. and CAMPBELL, C. D. 2002. Microbial communities in different soil types do not converge after diesel contamination. J. Appl. Microbiol., 92(2): 276-288.

CHINMAYEE, M. D., MAHESH, B., PRADESH, S., MINI, I. and SWAPNA, T. S. 2012. The Assessment of Phytoremediation Potential of Invasive Weed Amaranthus spinosus. Appl Biochem Biotechnol., 167(6): 1550-1559.

DWIVEDI, B. S. and BAGHEL, S. S. 2015. Determination of $\mathrm{pH}$ and Electrical Conductivity in Soil Samples. In: DWIVEDI, B. S., SHARMA, G. D., AMULE, F. C., TAGORE, G. S., DWIVEDI, A. K. and MITRA, N. G. (Eds.). Laboratory Manual on Soil and Plant Analysis. Jabalpur, India: Centre of Advanced Faculty Training, pp. 11-12.

EKPO, M. A. and NWANKPA, L. I. 2005. Effect of Crude on Microorganisms and Growth of Ginger (Zingba officinate) in the Tropics. Journal of Sustainable Tropical Agricultural Research, 16: 67-71.

INCKOT, R. C., SANTOS, G. D. O., DE SOUZA, L. A. and BONA, C. 2011. Germination and Development of Mimosa pilulifera in Petroleum-Contaminated Soil and Bioremediated Soil.Flora - Morphol. Distrib. Funct. Ecol. Plants, 206: 261-266.

KYUNG-HWA, B., HEE-SIK, K., HEE-MOCK, O., BYUNG-DAE, Y., JAISOO, K. and IN-SOOK, L. 2004. Effects of Crude Oil, Oil Components and Bioremediation on Plant Growth. Journal of Environmental Science and Health, 39(9): 2465-2472.

MERKL, N., SCHULTZE-KRAFT, R. and INFANTE, C. 2005. Assessment of tropical grasses and legumes for phytoremediation of petroleum contaminated soils. Water Air Soil Pollut., 165: 195-209.

MOLINA-BARAHONA, L., VEGA-LOYO, L., GUERRERO, M., RAMIREZ, S., ROMERO, I., VEGA-JARQUIN, C. and ALBORES, A. 2005. Evaluation of Diesel-Contaminated Soil Before and After a Bioremediation Process. Enviromental toxicology, 20(1): 100-109.

NELSON, D. W. and SOMMERS, L. E. 1986. Total Carbon, Organic Carbon and Organic Matter. In: PAGE, A. L. (Ed.). Methods of soil analysis, Part 2. Madison: America Society of Agronomy, pp. 961-1010.

NJOKU, K. L., AKINOLA, M. O. and OBOH, B. O. 2008. Growth and Performance of Glycine max L. (Merrill) Grown in Crude Oil Contaminated Soil Augmented with Cow Dung. Nature and Science, 6(1): 48-56.

NWADINIGWE, A. O. and ONYEIDU, E. G. 2012. Bioremediation of Crude Oil Polluted Soil using Bacteria and Poultry Manure Monitored through Soybean Productivity. Polish Journal of Environmental Studies, 21(1): 171-176.

OGBO, E. M., ZIBIGHA, M. and ODOGU, G. 2009. The effect of crude oil on growth of the weed (Paspalum scrobiculatum L.) - phytoremediation potential of the plant. African Journal of Environmental Science and Technology, 3(9): 229-233.

OKOYE, N. F., MONAGO-IGHORODGE, C. C., COMFORT, C. and AKPOBASAHA, N. A. 2017. Evaluating the use of spiny pigweed (Amaranthus Spinosus) and Water Leaf (Talinum Triangulare) for Bioremediation of Crude Oil polluted Soil in Ikarama Community in Bayelsa State Nigeria. Journal of Applied Science and Environmental Management, 21(5): 903-910.

OLSON, P. E., CASTRO, A., JOERN, M., DUTEAU, N. M., PILON-SMITS, E. A. H. and REARDON, K. F. 2007. Comparison of Plant Families in a Greenhouse Phytoremediation Study on an Aged Polycyclic Aromatic Hydrocarbon-Contaminated Soil. J Environ. Qual., 36(5): 1461-1469.

ONWURAH, I. N. E., OGUGUA, V. N., ONYIKE, N. B., OCHONOGOR, A. E. and OTITOJU, O. F. 2007. Crude Oil Spills in the Environment, Effects and Some Innovative Clean-up Biotechnologies. International Journal of Environmental Research, 1(4): 307-320.

OSAIGBOVO, A. U., LAW-OGBOMO, K. E. and AGELE, S. O. 2013. Effects of spent engine oil polluted soil and organic amendment on soil chemical properties, micro-flora on growth and herbage of Telfairia occidentalis (Hook F). Bayero Journal of Pure and Applied Sciences, 6(1): 72-78.

PANSU, M. and GAUTHEYROU, J. 2003. Handbook of Soil Analysis: Mineralogical, Organic and Inorganic Methods. New York: Springer. 
RASTOGI, A. and SHUKLA, S. 2013. Amaranth: A New Millennium Crop of Nutraceutical Values. Critical Reviews in Food Science and Nutrition, 53(2): 109-125.

REHAMAN, S., EL-SHEIKH, M. A., ALFARHAN, A. H. and USHANI, U. 2020. Spectral studies of Amaranthus tristis Linn. in Bioremediated Silk dyeing effluent with mixed biofertilizer inoculants. Saudi Journal of Biological Sciences, 28(2): 1203-1212.

SIVARAMAKRISHNAN, R., RAMPRAKASH, B., RAMADOSS, G., SURESH, S., PUGAZHENDHI, A. and INCHAROENSAKDI, A. 2021. High potential of Rhizopus treated rice bran waste for the nutrientfree anaerobic fermentative biohydrogen production. Bioresource Technology, 319: 124193.

SMITH, M. J., FLOWERS, T. H., DUNCAN, H. J. and ALDER, J. 2006. Effects of Polycyclic Aromatic Hydrocarbons on Germination and Subsequent Growth of Grasses and Legumes in Freshly Contaminated Soil and Soil with Aged PAHs Residues. Environ. Pollut., 141(3): 519-525.

SMITHA, P. A. 2010. Fordder Productivity and Quality of amaranth genotypes under different row spacing and seed rate. M. Sc. (Agri.) Thesis. Uni. Agric. Sci., Bangalore, Karkanata, India.

TONGOS, M. D. 2016. Growth Rate of Vegetable Amaranth (Amaranthus Cruentus L.) as Influenced by Row Spacing and Nitrogen Fertilizer in Mubi, Northern Guinea Savannah Zone, Nigeria. International Journal of Innovative Agriculture \& Biology Research, 4(2): 8-20.

UMANA, S. I., UKO, M. P., BASSEY, M. P. and ESSIEN, J. P. 2017. Hydrocarbons degrading potential of stimulated cultures of bacteria isolated from Humic fresh water sediment of Eniong River in the Niger Delta of Nigeria. Microb. Res. J. Int., 21(3): 1-13.

WANG, Y., FENG, J., LIN, Q., LYU, X., WANG, X. and WANG, G. 2013. Effects of crude oil contamination on soil physical and chemical properties in Momoge Wetland of China. Chinese Geo. Sci., 23(6): 708-715.

YERIMA, M. B., AGINA, S. E., UMAR, A. F., ANIBASA, U., EBUNUWA, A. and NASIR, A. M. 2013. Bacterial Degradation of Crude Oil Components Using Brewery Effluents as Biostimulation Agents. Vivechan international journal of research, 4: 10-17. 